\title{
Formulation of strategic development priorities of the Republic of Groatia
}

\author{
ANTO BAJO Institute of Public Finance \\ SAŠA LJEPOVIĆ Groatian National Bank ${ }^{\mathrm{I}}$
}

As an EU Member State, Croatia is obliged to implement the Europe 2020 strategy. Moreover, it has recently decided to join the regional strategy SEE 2O2O, under which it has defined eleven headline targets, as ambitious as the targets set by other participating countries. As a participant in both EU strategic initiatives, Croatia has set itself sixteen headline targets and a number of reform measures and development priorities until 2020. While welcoming these processes, Croatia, regretfully, still lacks a uniform national development strategy. In the absence of an umbrella strategy document, three documents are currently in force, namely the National Reform Programme, Convergence Programme and Partnership Agreement, which, together with several economically relevant sectoral strategies, constitute the backbone of the next strategy cycle until 2020.

\section{INTRODUCTION}

In May 20I4, the European Commission (hereinafter: Commission) started a review of the umbrella strategy EU 202O, which will include assessing the Member States' performance in its implementation and measuring progress in meeting five headline targets of the strategy. As an EU Member State, Croatia has an obligation to implement the EU 2020 strategy, but it has also decided to voluntarily join the Commission's regional strategic initiative SEE $2 \mathrm{O}^{2} \mathrm{O}^{2}$, aimed at interconnecting non-EU countries in the region.

The EU Member States' performance in the implementation of Europe 2020 is monitored within the European Semester (hereinafter: Semester), a key tool for EU economic governance. It is an annual cycle lasting from December to July, during which the Member States interact frequently with the Commission, exchanging reports required for the monitoring of national macroeconomic, fiscal and structural policies and their alignment with the EU economic policy3. The Semester includes two procedures that Croatia's

\footnotetext{
I The views of Saša Ljepović, expressed in this article are exclusively his own and do not necessarily represent those of the institution with which he is employed, nor are they in any way binding upon it.

${ }^{2}$ An acronym for South-East Europe 2020.

${ }^{3}$ The process officially begins usually in December with the publication of the Commission's Annual Growth Survey, and ends in July, when the EU Council adopts its country-specific recommendations.
} 
Government is familiar with very well: the Excessive Deficit Procedure and the Macroeconomic Imbalances Procedure ${ }^{4}$.

In accordance with the Semester rules, the Government on 24 April 2014 adopted a National Reform Programme and a Convergence Programme.

The National Reform Programme includes reform measures in four key areas: public finances, financial sector, labour market and competitiveness, and it measures progress in meeting five headline targets of the EU 2020 strategy. Under the Programme, the Commission has issued eight country-specific recommendations to be implemented by Croatia and taken into account in the formulation of the National Budget 20155.

In its Convergence Programme, the Government has presented measures aimed at improving the quality of public finances and medium-term macroeconomic projections, including fiscal targets. Under the Excessive Deficit Procedure, Croatia has accepted EU Council recommendations and set its general government deficit targets of $4.4 \%, 3.5 \%$ and $2.7 \%$ of GDP in 20I4, 2015 and 2016 respectively.

\section{THE EU 2020 STRATEGY AND ITS REVIEW}

Given that a half of the envisaged EU 2020 implementation period expires in 2015 and that legislative changes in the economic governance are underway in response to the crisis, the EU institutions have decided that it is the right time for a Strategy review. ${ }^{6}$ It is significant that the review coincides with the current institutional transition at the EU level, as the conclusions which will arise from the reviewing process will most likely constitute the basis for the policy initiatives of new assemblies of the European Parliament and Council during their first years in office (Andor, 20I4).

The process started on 5 March 20I4, as the Commission issued a communication entitled „Taking stock of the Europe 2020 strategy for smart, sustainable and inclusive growth”, in which it reported on the progress made so far in meeting five headline targets by each Member State, including Croatia. Since then, the Strategy reviews have often been on the regular meeting agendas of the EU Council's bodies, and have even become one of the priorities of the Italian presidency of the Council (from July to December 20I4). Moreover, the European Council on 27 June 20I4 presented a "Strategic Agenda for the Union in Times of Change", based on five priorities, with which the reviewed strategy will be aligned.

The Commission will, early in 2015, present a proposal for the strategy review, and the final decision of the European Council on the adoption of a revised Strategy for the period 2015-2020 is expected in March 20I5. Currently, public consultation is underway with EU citizens (including the Croatian ones), who are invited to submit their views and fill out a questionnaire?

\section{HEADLINE TARGETS OF EU 2020}

The Commission's Strategy features five headline targets for five different areas, reflecting the targeted level of development in the EU.

\footnotetext{
${ }^{4}$ In broader terms, the Macroeconomic Imbalances Procedure, introduced in December 20II, can be viewed as part of current changes in the EU economic governance which include, among other things, the introduction of a new set of rules on the financial system, aimed at creating a stable banking union, such as the directive on the recovery and resolution of credit institutions and investment firms.

5 The Country-Specific Recommendations - CSR) are aimed at eight areas: public finances, pension insurance and health care systems, labour market and education, social welfare, public administration and business environment, state property management, judicial system and banking system.

${ }^{6}$ The previous Lisbon Strategy (adopted in 200o) was also reviewed, for the first time in the middle of its ten-year implementation period (in 2005), and for the second time in 2008.

${ }^{7}$ Available at: http://ec.europa.eu/europe2020/public-consultation/index_hr.htm.
} 


\section{Table I.}

Strategic targets of EU 2020

\begin{tabular}{|c|c|}
\hline & Targets: \\
\hline I & $75 \%$ of the $20-64$ year-olds to be employed \\
\hline 2 & $3 \%$ of the EU's GDP to be invested in R\&D \\
\hline 3 & $\begin{array}{l}\text { greenhouse gas emissions } 20 \% \text { (or even } 30 \% \text {, if the conditions are right) lower than in } 1990 ; 20 \% \text { of energy from } \\
\text { renewables; a 20\% increase in energy efficiency }\end{array}$ \\
\hline 4 & $\begin{array}{l}\text { reducing the rates of early school leaving below IO\% for I8-24-year olds; increasing the share of 30-34-year-olds } \\
\text { completing third-level education to at least } 40 \%\end{array}$ \\
\hline 5 & Reducing, by at least 20 million, the number of people in or at risk of poverty and social exclusion \\
\hline
\end{tabular}

\section{MEETING THE STRATEGIC TARGETS OF EU 2020 IN GROATIA}

Each Member State has defined its national target values in order to make them both ambitious and achievable. Meeting these targets is not a legal obligation, but rather a political issue. Croatia has been implementing the EU 2020 strategy for only a year now and, according to current indicators, its position in this respect is relatively worse than the positions of most other Member States.

Croatia's first headline target is to achieve an employment rate of $62.9 \%$ by 2020 , which is the lowest target level compared to the levels of other Member States (Graph I). However, this rate is ambitious enough for Croatia, given that in 2013 only Greece had a lower employment rate than Croatia (53.9\%). In the pre-recession year 2008, employment in Croatia stood at $62.9 \%$, but it declined steadily over the next five years. The goal is to restore the employment rate to its pre-crisis level by 2020 .

The second headline target is to invest $1.4 \%$ of the national GDP annually in R\&D by 202O, which is the fourth lowest target value in the EU, after the values set by Cyprus, Slovakia and Greece (Graph 2). In 2012, Croatia invested 0.75\% of GDP in R\&D, more than Greece, Latvia, Bulgaria, Romania and Cyprus, and it will try to almost double that rate in the next six years. This is a highly ambitious goal, given that, in the last twelve years, Croatia's annual investment in R\&D never exceeded 1.05\% of GDP, and that it recorded the lowest average annual increase in investment in R\&D in the EU over the same period. It will be much easier for Slovenia, for example, to achieve its 3\% target, because it invested $2.8 \%$ of GDP in research and development as early as 2012. Finland and Sweden are at the very top of the list and, as suggested by their targets of investing as much as $4 \%$ of GDP in R\&D by 2020 , they are very likely to stay there.

With respect to climate change and energy sustainability, Croatia's position is satisfactory, and its set targets are likely to be achieved. National targets are used to measure greenhouse gas emissions in the sectors not included in the EU Emissions Trading System, relative to the emission levels in $2005^{8}$. In 20IO, Croatia's emissions of carbon dioxide equivalent stood at 20.I million tonnes, up $0.7 \%$ on the reference year 2005. This level is so far enough to meet the target, because it is still below the agreed national limit allowing an 9.2\% increase in emissions by 2020 (Graph 3 ).

When it comes to the share of energy from renewables in gross final energy consumption in 20I2, Croatia ranks IIth among the EU member States, and is very close to the national target of $20 \%$. This share stood at 12.I\% in 2008, but has grown steadily year-on-year over the recession period (Graph 4). Croatia has no official target for primary energy saving, but, under the national Energy Strategy, it committed itself to supporting the EU target of reducing the primary energy consumption by $20 \%$ from

\footnotetext{
${ }^{8}$ The headline target of reducing greenhouse gas emissions by at least $20 \%$ by 2020 from 1990 implies the following: a) a $21 \%$ emissions reduction at the EU level in sectors included in the EU Emissions Trading System; and b) a IO\% emissions reduction at the EU level in sectors outside the system. In order to achieve the total reduction target of 10\%, each Member State has set a national emissions limit for 2020 relative to 2005 emissions levels, in accordance with the Decision of the European Parliament and of the Council (406/2009/EC).
} 
the baseline projection (Ministry of Economy, 2013)9. Thus, I7 countries, including Croatia, met their indicative national energy efficiency targets in 2012, because their primary energy consumption levels remained below the target level (Graph 5). From 2008 to 2012, Croatia saw a fall in primary energy consumption, which, as in most other Member States during the recession, was more the consequence of an economic slowdown than higher energy efficiency.

Croatia's target in the area of education is to reduce the share of early leavers from education and training (aged I8 to 24 years) to as little as $4 \%$ by 2020, the lowest rate in the EU. By contrast, this target's value in Italy is the highest, $16 \%$ (Graph 6). Given that Croatia's early school-leaving rate was the lowest in the EU in 2013 as well, the Commission deems that the country will be able to achieve the set target over the next six years. Spain and Portugal, for example, will have difficulty in achieving their targets ( $15 \%$ and $10 \%$ respectively), because their current rates stand at $23.6 \%$ and $19.2 \%$ respectively.

Croatia will also try to have $35 \%$ of the younger population (aged 30-34 years) with a tertiary degree. This target can be considered ambitious, given that this rate was $25.9 \%$ in 20I3, the third lowest rate in the EU after the rates in Romania and Italy (Graph 7). It is noteworthy, however, that the share of this population in Croatia stood at $16.7 \%$ in 2007, growing steadily over the last six years (except 20I2).

Accordingly, during the recession, the share of highly educated population (aged 30-34 years) increased; the share of early school-leavers (aged 18-24 years) fell to the level of 2008 in 2013, but at the same time, the number of employees (aged 20-64 years) decreased. All this confirms the Commission's conclusion that the observed satisfactory progress towards achieving the targets in the education area is largely attributable to increased demand for education in response to reduced employment opportunities.

Croatia's last strategic target is to reduce the number of people in or at risk of poverty and social exclusion by 150,000 , i. e. from I,370,000 (in 2012) to I,220,000 by 2020. The Member States were required to set the targeted amounts of reduction in millions of inhabitants. Hence, in its report, the Commission notes that the aggregated national target values correspond to a reduction by approximately $\mathrm{I} 2$ million people, down 8 million from the 20 million target set for the $\mathrm{EU}^{\text {Io }}$. With its share of $32.3 \%$ of the population in or at risk of poverty and social exclusion in 2012, Croatia was among relatively risky countries, followed by Hungary, Lithuania, Greece, Latvia, Romania and Bulgaria (with shares of almost half of the population) (Graph 8).

\section{THE SEE 2020 STRATEGY}

Croatia has accepted a joint initiative to participate in the SEE 2020 strategy process, endorsed by the Commission, together with other participants, i.e. Albania, Bosnia and Herzegovina, Kosovo, Macedonia, Montenegro and Serbia. The strategy has been developed along the lines of the EU 2020 strategy. ${ }^{\mathrm{II}}$

The purpose of SEE 2020 is economic cooperation among countries in the region, aimed at increasing competitiveness and achieving higher levels of growth, as well as facilitating social and institutional development through the adoption of reform policies. The expected outcome is a long-term acceleration of effective convergence towards the EU and increased preparedness for future EU membership

\footnotetext{
${ }^{9}$ According to the Directive 2OI2/27/EU of the European Parliament and of the Council, energy consumption in EU 27 in 2020 may not exceed I,474 million tonnes of oil equivalent for primary energy, or I,O78 million tonnes of oil equivalent for direct (final) energy consumption. Upon Croatia's accession to the EU, the limits for EU 28 were raised to I,483 million and I,O86 million tonnes respectively. In accordance with these limits, the Member States should set their own indicative national targets.

Io The definition of the risk of poverty and social exclusion in terms of the EU 2020 target is interpreted differently in different EU Member States. The target values of all the Member States can be found in the document "2OI4 European Semester: Countryspecific recommendations".

II The preparation of the strategy and monitoring of its implementation is coordinated by the newly established Regional Cooperation Council - RCC), and the document was approved by the economy ministers of the countries in the region.
} 
negotiations. By joining this initiative, Croatia will be able to share its experience in establishing and adaptation of institutions necessary for active participation in the international strategic and EU accession processes.

The main concept of SEE $202 \mathrm{O}$ is similar to that of EU 2020 and is based on five pillars of economic growth (smart, sustainable, inclusive and integrated growth and governance for growth), covering a total of sixteen areas ${ }^{12}$. The strategy includes eleven headline targets for the region, and each participating country sets its own national target values which it tries to realise by 2020. Eight out of the stated eleven headline targets for the region, have been classified according to five pillars of growth, while the remaining three constitute umbrella strategic targets for the region. In short, the main targets of SEE 2020 are:

- to increase GDP per capita to $44 \%$ of the EU average;

- to more than double the total value of trade in goods and services relative to that in 2010 (the targeted value is 209.5 billion euros); and

- to narrow the trade balance deficit to $12.3 \%$ of GDP.

The Regional Cooperation Council's Report from June 2014 features an analysis of the situation in the SEE 2020 participating countries with respect to national target indicators in the period 2010-2013. It has been found that, according to most key indicators, certain progress has been made in achieving the set targets, but at a slower rate than expected.

A comparison of the headline target values between Croatia and other countries in the region shows that Croatia has set the highest standards with respect to six out of eleven targets, including three umbrella strategic targets (Table I). This is expected, given that, according to its GDP per capita, Croatia is the most developed country in the region; in 2012, its GDP per capita stood at a high of $64 \%$ of the EU average, followed by Montenegro (41\%), Serbia (36\%), Macedonia (35\%), Albania (30\%), Bosnia and Herzegovina (29\%) and Kosovo (23\%).

As suggested by indicators for the period 2010-2013, some targets have been set too ambitiously by most of the countries, i. e., given the current trend, they are not likely to be achieved. Thus, for example in Croatia, total trade in goods and services should grow by II $8 \%$ by 2020 from 20I3; the exports of goods and services per capita by 109\% relative to those in 2013 and intra-regional trade in goods by 106\% relative to that in 2012. The targets set by other countries in the region are similarly unrealistic.

As an EU Member State, Croatia has free access to the European Single Market and it can use the potential of the available regional market. The macroeconomic environment and growth dynamics in the region are largely determined by the fact that trade with the EU accounts for $60 \%$ of its total trade and that Croatia and Serbia jointly account for 60\% of the region's GDP (Regional Cooperation Council, 20I4). While within the EU, Croatia constantly has to catch up with developed Member States, within the SEE 2O2O, it should be a leader and promoter of the region's economic growth and competitiveness.

\section{STRATEGIG DEVELOPMENT DOGUMENTS OF THE REPUBLIC OF GROATIA}

Croatia currently has no uniform national strategy to serve as an umbrella strategic document briefly outlining the course of development of the country. The last such document was the Strategic Development Framework 2006-2013. Although the period to which the document related formally expired at the end of 2013, it had lost its relevance even earlier, namely after the first negative effects of the crisis in Croatia had come to light, and has therefore been rarely referred to since 20Io. More specifically, although the strategic framework identified major obstacles to growth and development, it

\footnotetext{
${ }^{12}$ Free trade, a competitive economic environment, global integration (investment policy), education and competences, $R \& D$ and innovation, digital society, cultural and creative sectors, energy, transport, environment, competitiveness, employment, health care, effective public services, anti-corruption and judiciary.
} 
did not envisage different growth scenarios, but only the optimistic one, and, given the inadequate elaboration of activity implementation monitoring system, it could not be implemented effectively.

However, Croatia currently has a number of strategic documents (strategies, plans and programmes) that are being, or will soon be implemented and that cover different socio-economic areas, also referred to in the EU strategies (Table 2). Twenty-five out of forty selected documents relate to the period up to $2 \mathrm{O} 2 \mathrm{O}$ or longer. The share is slightly larger if the National Reform Programme, Convergence Programme and Economic and Fiscal Policy Guidelines ${ }^{13}$, to be prepared annually, are left out of the calculation. It can therefore be concluded that most of these documents cover the same period as the EU strategic processes (until 2020). ${ }^{\mathrm{I}}$

The first four documents (listed in Table 2) can be characterized as being horizontal, whereas the others are related to particular socio-economic sectors. The Partnership Agreement is considered horizontal, because it constitutes a programming document, outlining a comprehensive national strategy for the EU structural and investment funds allocation in the financial period 2014-2020, in amounts exceeding Io billion euros, by areas, in accordance with EU $202 \mathrm{O}^{15}$.

The finalisation of this document is the main prerequisite for the utilization of EU funds, and its approval by the Commission is expected in October 2014.

In the absence of an umbrella strategic document for the period 2014-2020, Croatia's development strategy is, at this point, primarily formulated in the National Reform Programme, Convergence Programme and Partnership Agreement, which, together with economically relevant sectoral strategies, such as the Industrial Strategy, Investment Promotion Strategy, Strategy for Education, Science and Technology, Entrepreneurship Development Strategy, Innovation Strategy and Tourism Development Strategy, constitute the backbone of the next strategy cycle until 2020.

\section{CONCLUSIONS}

Croatia is in a specific situation, due to its participation in two EU strategic plans - EU 2O2O and SEE 2O2O, which made it possible for the country to formulate sixteen headline targets and a number of reform measures and development priorities. The country's performance on the EU 2020 headline targets is currently satisfactory. After a one-year implementation of the strategy, Croatia's rankings on the employment, R\&D, poverty and (partly) education targets (higher education) are worse than those of most other Member States. Nevertheless, its position with respect to environmental protection and energy efficiency and, partly, education (early leaving from education and training) targets has relatively improved.

The implementation of EU $2 \mathrm{O} 2 \mathrm{O}$ is much more demanding for Croatia than that of SEE 2O2O, because the obligatory participation in the former strategy involves regular reporting on performance in meeting the headline targets, but also on the fiscal and macroeconomic indicators within the Excessive Deficit Procedure and Macroeconomic Imbalances Procedure. Consequently, Croatia's overall performance in the implementation of the EU 2020 strategy will be shown only in the next medium-term period.

\footnotetext{
${ }^{13}$ The fiscal indicators presented in the Economic and Fiscal Policy Guidelines must be in line with those in the Convergence Programme, as required by the European Semester. However, the document releases for 20I4 are not aligned, due to different time dynamics of their preparation. As Croatia formally participates in the European Semester for the first time in 20I4, the Guidelines had already been issued before the Convergence Programme was submitted to the European Commission.

${ }^{14}$ Including the Nautical Tourism Development Strategy, adopted for the period until 2019.

${ }_{15}$ The draft document, Croatia sent to the European Commission for assessment on 22 April 20I4, features six top funding priorities: I) innovative and competitive business and research environment; 2) promoting energy efficiency, renewable energies and protecting natural resources; 3) sustainable and modern transport and network infrastructure; 4) enhancing labour market participation and quality of the education system; 5) active inclusion and reduction of poverty; and 6) supporting the quality, effectiveness and efficiency of public administration and judiciary. In the area of rural development, agriculture and fisheries, funding priorities have also been established that contribute to the EU Common Agricultural Policy and Common Fisheries Policy.
} 
The Government should formulate a national development strategy for the period until 2020, which is the next EU strategy cycle, thus synchronizing it with EU 2020 and SEE 202O, i.e. with the EU's new multiannual financial framework and financial period for the use of EU funds (2014-2020). This document should include all current goals, priorities and activities arising from the EU strategic processes, especially EU 202O, which should be integrated with Croatia's own strategic development priorities in areas further elaborated under the sectoral strategies. The national development strategy, once formulated, may have a positive influence on the mutual alignment of existing sectoral strategy documents and sectoral policy coordination, and, given an efficient implementation monitoring system, on the achievement of the set targets as well.

\section{LITERATURE}

Andor, L., 20I4. Speech: The Europe 2020 Strategy beyond the crisis. Brussels: European Commission.

Council of the EU, 20I4a. Background Note of the Italian Presidency - Review of the Europe 2020 Strategy. Bruxelles: Council of the EU (ECOFIN).

Council of the EU, 20I4b. Programme of the Italian Presidency of Council of the EU. B Brussels: Council of the EU.

European Commission, 2010. Europe 2020 - A strategy for smart, sustainable and inclusive growth. Brussels: European Commission.

European Commission, 2013. Smarter, greener, more inclusive? - Indicators to support the Europe 2020 Strategy - 2013 edition. Brussels: European Commission.

European Commission, 20I4. Communication from the Commission to the European Parliament, the Council, the European Economic and Social Committee and the Committee of the Regions - 2014 European Semester: Country-specific recommendations. Brussels: European Commission.

European Commission, 20I4a. Communication from the Commission to the European Parliament, the Council, the European Economic and Social Committee and the Committee of the Regions - Taking Stock of the Europe 2020 Strategy for Smart, Sustainable and Inclusive Growth and the Annex pertaining thereto. Brussels: European Commission.

European Commission, 20I4b. Country-specific Recommendations for Croatia - Recommendation for a Council Recommendation on Croatia's 2OI4 national reform programme and delivering a Council opinion on Croatia's 2014 convergence programme. Brussels: European Commission.

European Council, 2010. European Council Conclusions of Io June 20Iо. Brussels: European Council.

European Council, 20I4. European Council Conclusions of 26 and 27 June 20I4. Brussels: European Council

Government of the RC, 2006. Strategic Development Framework for 2006-20I3. Zagreb: Government of the RC.

Government of the RC, 20I4a. National Reform Programme. Zagreb: Government of the RC.

Government of the RC, 20I4b. Convergence Programme of the Republic of Croatia for the Period 20I4-20I7. Zagreb: Government of the RC.

Ministarstvo gospodarstva, 2013. Second National Energy Efficiency Action Plan for the Period until the End of 20I3. Zagreb: Ministarstvo gospodarstva : Ministarstvo graditeljstva i prostornoga uređenja.

Ministry of Regional Development and EU Funds, Ministry of Labour and Pension System and Ministry of Agriculture, 20I4. Official proposal for a Partnership Agreement for the European Structural and Investment Funds in the EU Financial Period 20I4-202O. Zagreb: Ministry of Regional Development and EU Funds.

Regional Cooperation Council, 2013. South East Europe 2020 Strategy. Sarajevo: Regional Cooperation Council.

Regional Cooperation Council, 20I4. SEE 2020 Baseline Report: Towards Regional Growth. Sarajevo: Regional Cooperation Council. 


\section{GRAPHS AND TABLES}

\section{Graph I.}

Employment rate, age group 20-64 (\%)

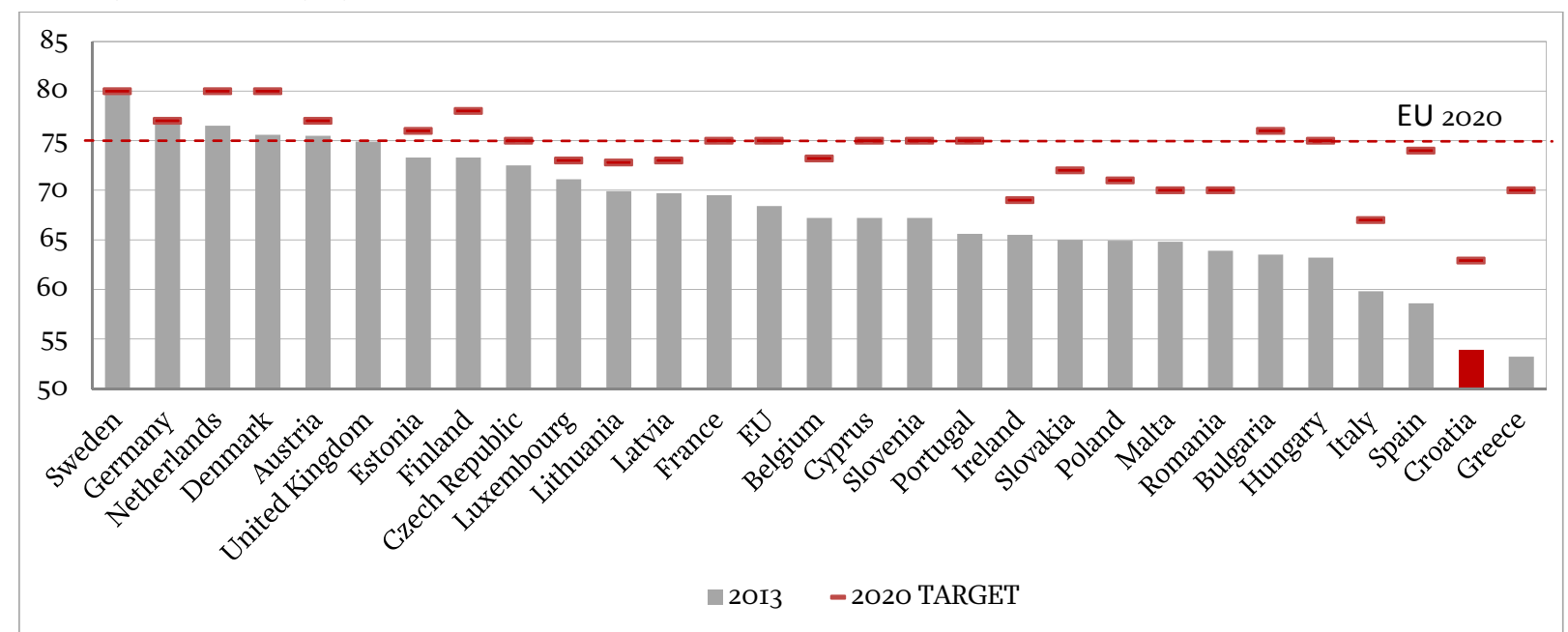

*United Kingdom has not set its target.

Source: Eurostat (Code: t2O2O_IO).

\section{Graph 2.}

Spending on R\&D (\% GDP)

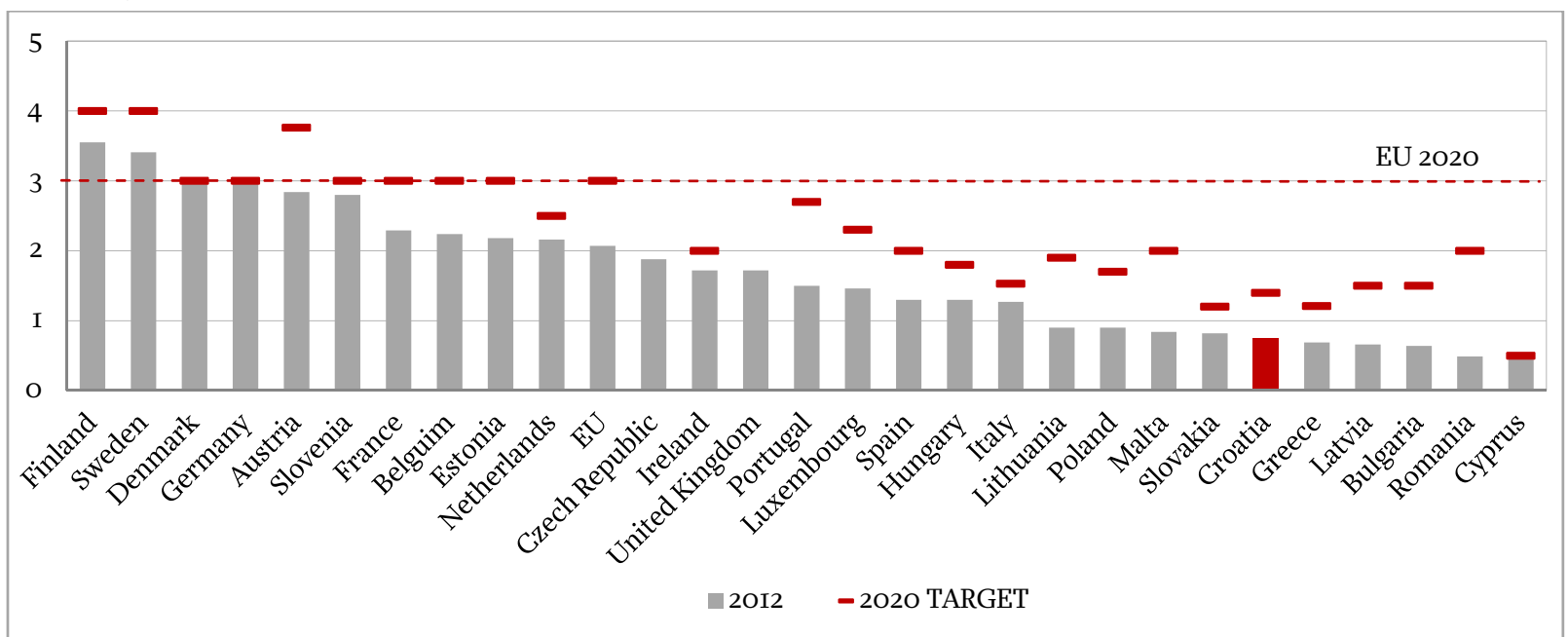

*United Kingdom has not set its target; Czech Republic has set a target for public sector only (I\% of GDP).

Source: Eurostat (Code: t2O2O_2O). 


\section{Graph 3.}

Greenhouse gas emissions in non-ETS (EU Emissions Trading System) sectors (million tonnes of CO2 equivalent)

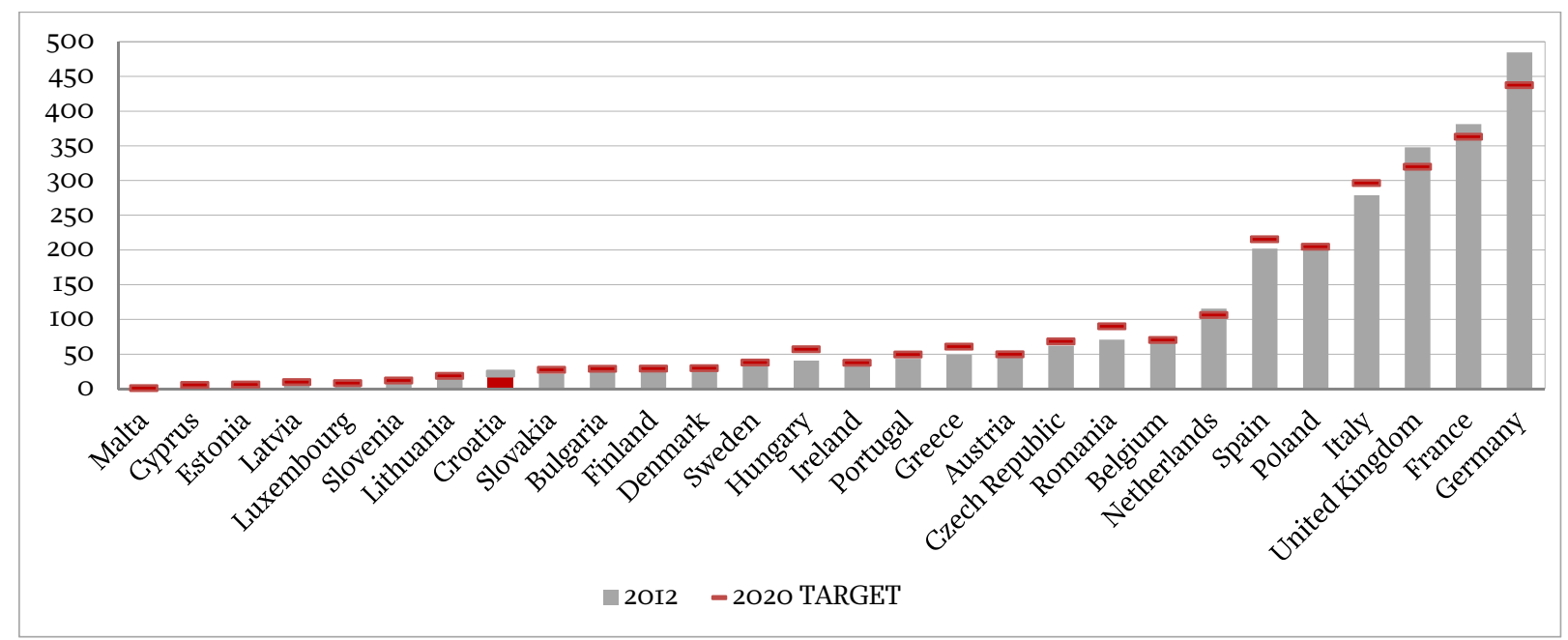

*The data for Croatia relates to 2010.

Source: Eurostat (Code: t2O2O_35).

\section{Graph 4.}

Share of renewable energy in gross final energy consumption (\%)

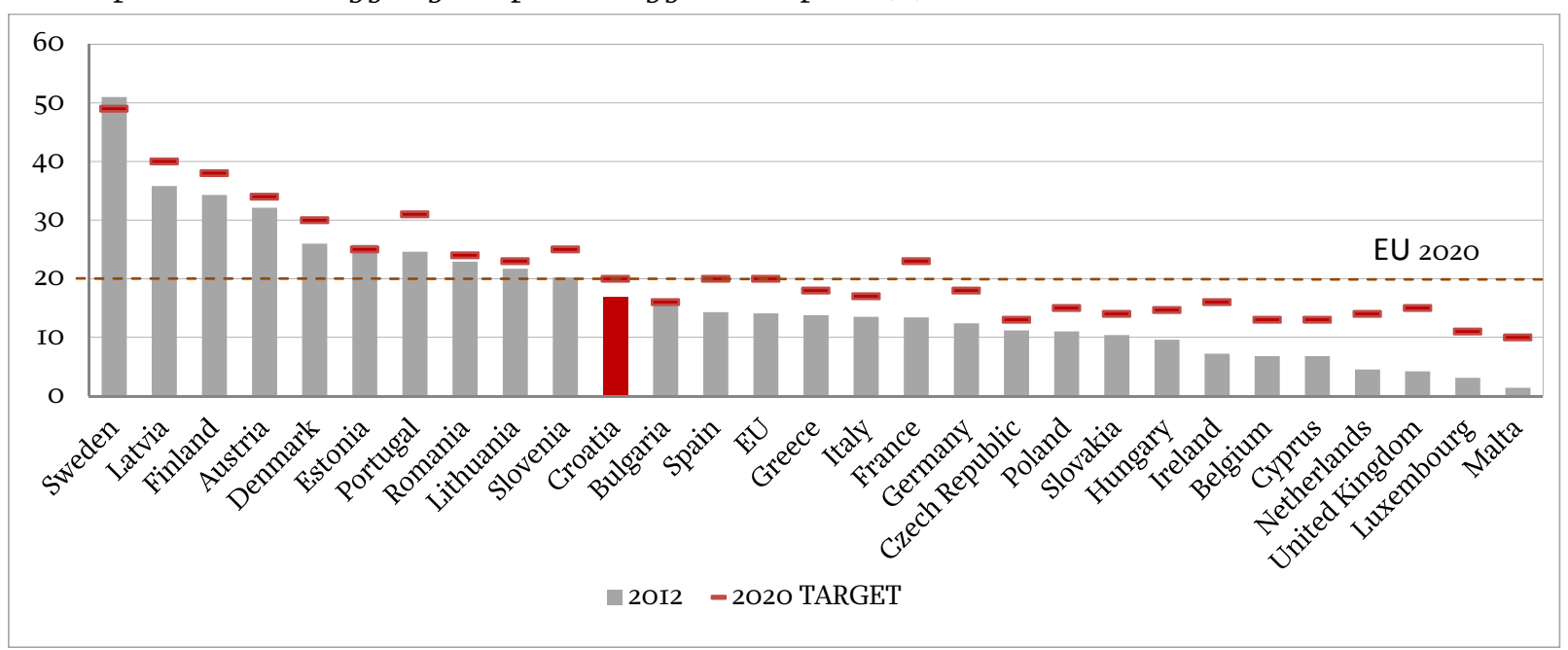

Source: Eurostat (Code: t2O2O_3I). 


\section{Graph 5 .}

Primary energy consumption (million tonnes of oil equivalent)

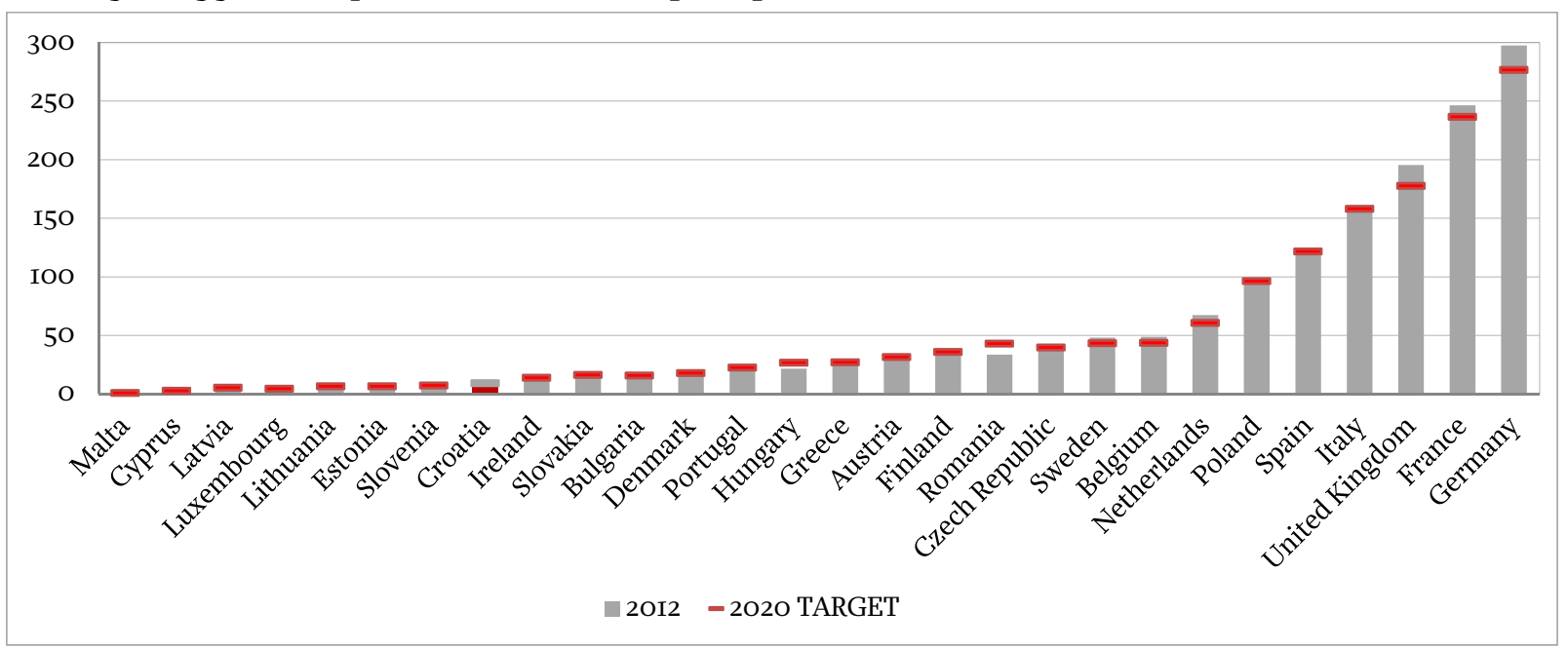

Source: European Commission.

\section{Graph 6.}

Share of the population aged 18-24, with at most lower secondary education and not in further education or training (\%)

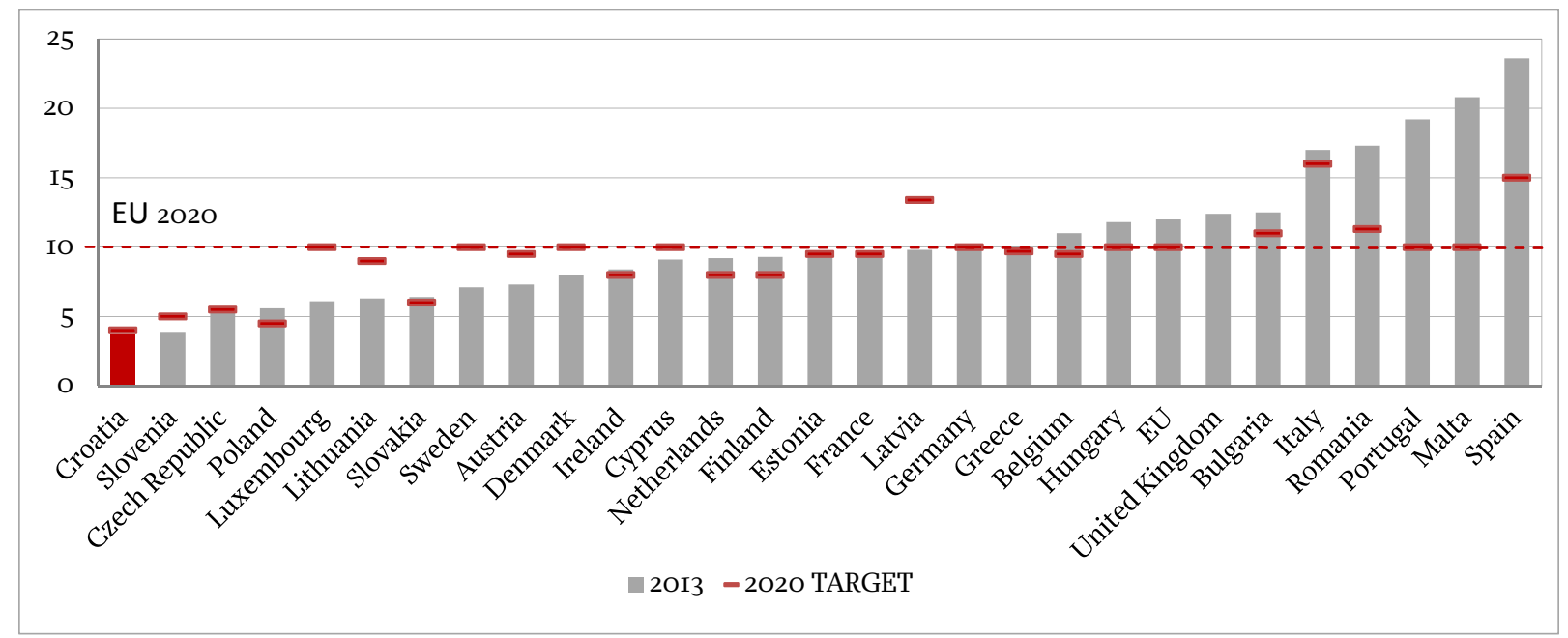

Source: Eurostat (Code: t202O_40). 
Graph 7.

Share of the population aged 30-34 years with tertiary education attainment, education level ISCED of 5-6 (\%)

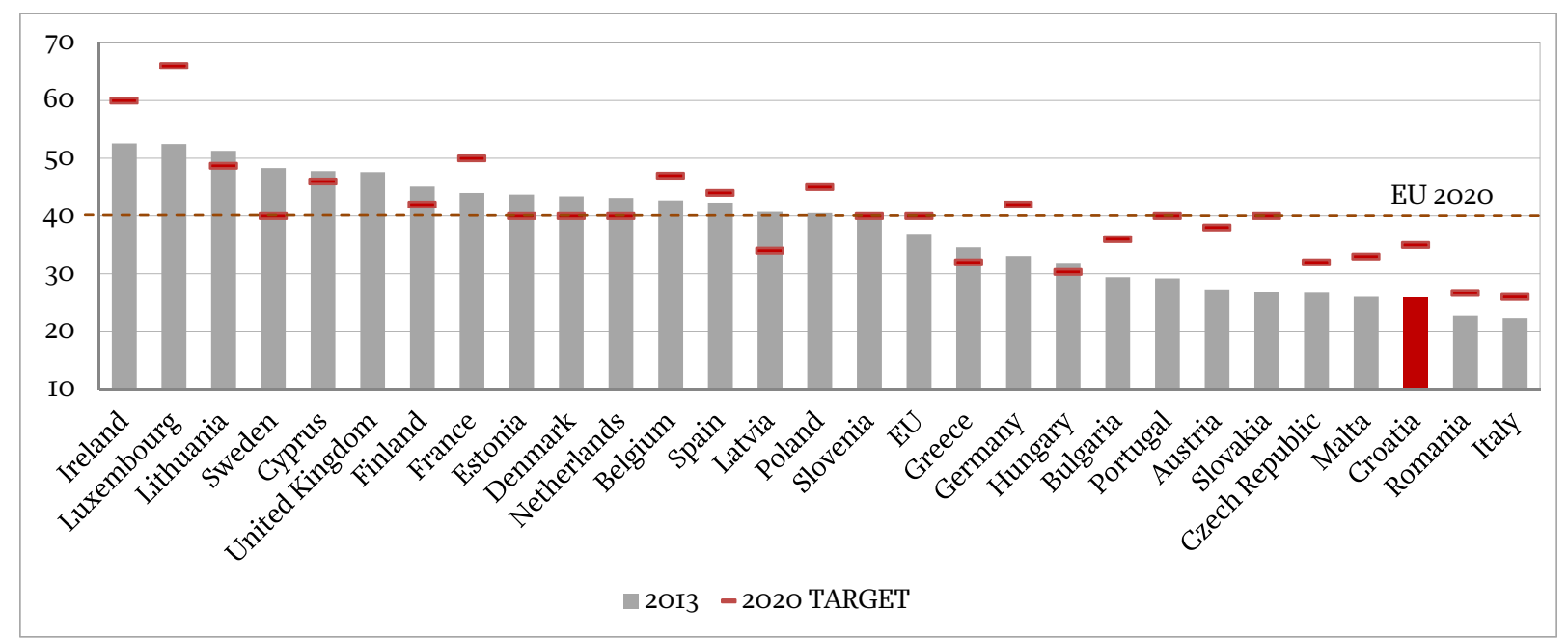

Source: Eurostat (Code: t2O2O_4I).

\section{Graph 8.}

Share of the population at risk of poverty or social exclusion, 2012 (\%)

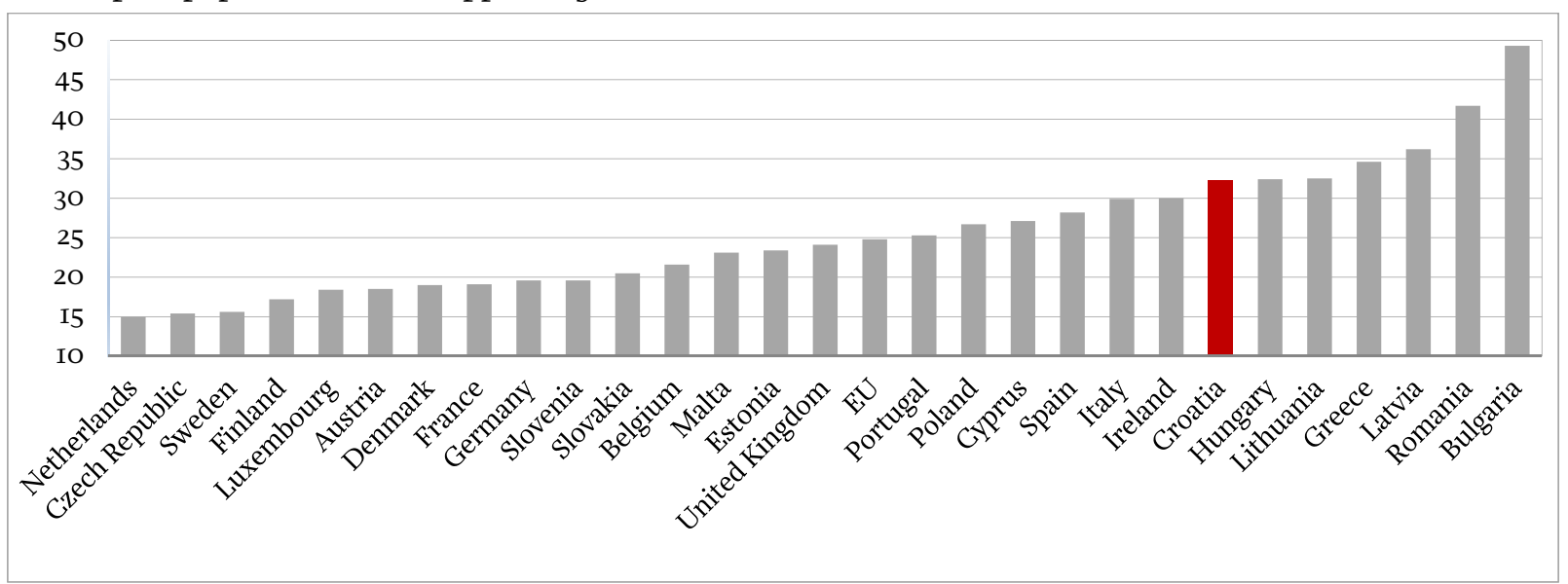

*The 20I3 data: Austria, Czech Republic, Estonia, Finland, Italy, Latvia, Hungary, Poland, Slovakia and Spain. Source: Eurostat (Code: t2O2O_50). 
Table I.

The SEE 2020 target values for Croatia, 201O-2013

\begin{tabular}{|c|c|c|c|c|c|c|c|}
\hline & Description & 2010 & 2011 & 2012 & 2013 & $\begin{array}{l}\text { HR } 2020 \\
\text { TARGET }\end{array}$ & $\begin{array}{l}\text { SEE } 2020 \\
\text { TARGET }\end{array}$ \\
\hline & \multicolumn{7}{|c|}{ Overall strategic targets } \\
\hline I. & $\begin{array}{l}\text { GDP per capita relative to the EU } \\
\text { average (in PPS), \% of EU-27 average }\end{array}$ & 59 & 60 & 64 & - & 68 & 44 \\
\hline 2. & $\begin{array}{l}\text { Total trade in goods and services } \\
\text { (EUR million) }\end{array}$ & 35,400 & 37,092 & 37,752 & 36,701 & 80,000 & 209,500 \\
\hline \multirow[t]{2}{*}{3.} & Trade balance (\% of GDP) & -3.8 & -O.I & 0.6 & 0.6 & -3.3 & -12.3 \\
\hline & \multicolumn{7}{|c|}{ Integrated growth } \\
\hline 4. & $\begin{array}{l}\text { Intra-regional trade in goods(EUR } \\
\text { million }\end{array}$ & 2,474 & 2,809 & 3,004 & - & 6,200 & 30,500 \\
\hline \multirow[t]{2}{*}{5.} & Overall FDI inflows (EUR million) & 326 & $\mathrm{I}, 087$ & I,066 & 437 & $\mathrm{I}, 500$ & 8,800 \\
\hline & \multicolumn{7}{|c|}{ Smart growth } \\
\hline 6. & GDP per person employed (EUR at PPS) & 40,990 & 43,765 & 50,028 & - & 52,000 & 36,300 \\
\hline \multirow[t]{2}{*}{7.} & $\begin{array}{l}\text { Number of highly qualified persons in } \\
\text { the workforce }\end{array}$ & 504,800 & $4 \mathrm{I} 8,000$ & 430,400 & 448,000 & 605,000 & 2,000,000 \\
\hline & \multicolumn{7}{|c|}{ Sustainable growth } \\
\hline 8. & $\begin{array}{l}\text { Net enterprise creation } \\
\text { (new businesses } \mathrm{p} / \mathrm{a} \text { ) }\end{array}$ & 7,800 & 8,778 & IO,543 & $-\mathrm{II}, 6 \mathrm{O} 3$ & 9,300 & 33,760 \\
\hline \multirow[t]{2}{*}{9.} & $\begin{array}{l}\text { Exports of goods and services per capita } \\
\text { (EUR) }\end{array}$ & $4, \mathrm{OIO}$ & 4,329 & $4,44 \mathrm{I}$ & $4,3 \mathrm{I} 4$ & 9,000 & 4,250 \\
\hline & \multicolumn{7}{|c|}{ Inclusive growth } \\
\hline \multirow[t]{2}{*}{ IO. } & $\begin{array}{l}\text { Overall employment rate, \% of } 15^{+} \\
\text {population }\end{array}$ & 4I.I & 39.5 & 38.I & 36.4 & 47.5 & 44.4 \\
\hline & \multicolumn{7}{|c|}{ Governance for growth } \\
\hline II. & $\begin{array}{l}\text { Governance effectiveness } \\
\text { (World Bank Governance Index) }\end{array}$ & 3.I & 3.I & 3.2 & - & 3.7 & 2.9 \\
\hline
\end{tabular}

Source: Regional Cooperation Council (SEE 2020 Baseline Report). 
Table 2.

Selected strategic documents currently in force in the Republic of Croatia

\begin{tabular}{|c|c|c|c|c|}
\hline & Document & $\begin{array}{l}\text { Implementation } \\
\text { period }\end{array}$ & $\begin{array}{l}\text { Responsible } \\
\text { institution }\end{array}$ & Status \\
\hline I & National Reform Programme & 20I4-20I6 & $\begin{array}{l}\text { Ministry of Regional } \\
\text { Development and EU } \\
\text { Funds }\end{array}$ & Completed \\
\hline 2 & $\begin{array}{l}\text { Convergence Programme of the Republic of } \\
\text { Croatia, 2OI4-2OI7 }\end{array}$ & 20I4-2OI7 & Ministry of Finance & Completed \\
\hline 3 & $\begin{array}{l}\text { Partnership Agreement for the European } \\
\text { Structural and Investment Funds in the } \\
\text { Financial Period 2014-202O }\end{array}$ & $2015-2023$ & $\begin{array}{l}\text { Ministry of Regional } \\
\text { Development and EU } \\
\text { Funds }\end{array}$ & $\begin{array}{l}\text { Under } \\
\text { preparation }\end{array}$ \\
\hline 4 & $\begin{array}{l}\text { Economic and Fiscal Policy Guidelines, 20I4- } \\
2016\end{array}$ & 20I4-20I6 & Ministry of Finance & Completed \\
\hline 5 & $\begin{array}{l}\text { Industrial Strategy of the Republic of Croatia, } \\
\text { 20I4-2O2O }\end{array}$ & $2 \mathrm{OI} 4-2 \mathrm{O} 2 \mathrm{O}$ & Ministry of Economy & Completed \\
\hline 6 & $\begin{array}{l}\text { Investment Promotion Strategy of the } \\
\text { Republic of Croatia, 2OI4-2O2O }\end{array}$ & $2014-2020$ & Ministry of Economy & $\begin{array}{l}\text { Under } \\
\text { preparation }\end{array}$ \\
\hline 7 & $\begin{array}{l}\text { Innovation Strategy of the Republic of Croatia, } \\
2 \mathrm{OI} 4-2 \mathrm{O} 2 \mathrm{O}\end{array}$ & $2 \mathrm{OI} 4-2 \mathrm{O} 2 \mathrm{O}$ & Ministry of Economy & $\begin{array}{l}\text { Under } \\
\text { preparation }\end{array}$ \\
\hline 8 & $\begin{array}{l}\text { Strategy for Education, Science and } \\
\text { Technology }\end{array}$ & $2014-2025$ & $\begin{array}{l}\text { Ministry of Science, } \\
\text { Education and Sports }\end{array}$ & $\begin{array}{l}\text { Under } \\
\text { preparation }\end{array}$ \\
\hline 9 & Smart Specialisation Strategy, 20I4-202O & $2 \mathrm{OI} 4-2 \mathrm{O} 2 \mathrm{O}$ & Ministry of Economy & $\begin{array}{l}\text { Under } \\
\text { preparation }\end{array}$ \\
\hline IO & Action Plan to Support Exports, 2014-2015 & 20I4-2OI5 & Government of the RC & Completed \\
\hline II & $\begin{array}{l}\text { Entrepreneurship Development Strategy of } \\
\text { the Republic of Croatia, 2013-202O }\end{array}$ & $2013-2020$ & $\begin{array}{l}\text { Ministry of } \\
\text { Entrepreneurship and } \\
\text { Crafts }\end{array}$ & Completed \\
\hline 12 & $\begin{array}{l}\text { Cluster Development Strategy of the Republic } \\
\text { of Croatia, 2OII-2O2O }\end{array}$ & $2 \mathrm{OII}-2 \mathrm{O} 2 \mathrm{O}$ & $\begin{array}{l}\text { Ministry of } \\
\text { Entrepreneurship } \\
\text { and Crafts }\end{array}$ & Completed \\
\hline I3 & $\begin{array}{l}\text { Women Entrepreneurship Development } \\
\text { Strategy of the Republic of Croatia, 2014 -2O2O }\end{array}$ & $2 \mathrm{OI} 4-2 \mathrm{O} 2 \mathrm{O}$ & $\begin{array}{l}\text { Ministry of } \\
\text { Entrepreneurship and } \\
\text { Crafts }\end{array}$ & Completed \\
\hline $\mathrm{I} 4$ & $\begin{array}{l}\text { Strategy for Social Entrepreneurship of the } \\
\text { Republic of Croatia, 20I4-202O }\end{array}$ & $2014-2020$ & $\begin{array}{l}\text { Ministry of Labour and } \\
\text { Pension System }\end{array}$ & $\begin{array}{l}\text { Under } \\
\text { preparation }\end{array}$ \\
\hline I5 & Youth Guarantee Implementation Plan & $2014-202 \mathrm{O}$ & $\begin{array}{l}\text { Ministry of Labour and } \\
\text { Pension System }\end{array}$ & Completed \\
\hline I6 & Energy Strategy of the Republic of Croatia & $2009-2020$ & Ministry of Economy & Completed \\
\hline 17 & $\begin{array}{l}\text { Tourism Development Strategy of the } \\
\text { Republic of Croatia until } 202 \mathrm{O}\end{array}$ & $2013 .-2020$ & Ministry of Tourism & Completed \\
\hline I8 & $\begin{array}{l}\text { Nautical Tourism Development Strategy of } \\
\text { the Republic of Croatia, 2009-2019 }\end{array}$ & 2009-2019 & $\begin{array}{l}\text { Ministry of Sea, } \\
\text { Transport and } \\
\text { Infrastructure }\end{array}$ & Completed \\
\hline I9 & $\begin{array}{l}\text { Transport Development Strategy of the } \\
\text { Republic of Croatia, 20I4-203O }\end{array}$ & 2014.-2030 & $\begin{array}{l}\text { Ministry of Sea, } \\
\text { Transport and } \\
\text { Infrastructure }\end{array}$ & $\begin{array}{l}\text { Under } \\
\text { preparation }\end{array}$ \\
\hline 20 & $\begin{array}{l}\text { Strategy for Maritime Development and } \\
\text { Integrated Maritime Policy of the Republic of } \\
\text { Croatia, 2OI4-202O }\end{array}$ & 2OI4.-2O2O & $\begin{array}{l}\text { Ministry of Sea, } \\
\text { Transport and } \\
\text { Infrastructure }\end{array}$ & Completed \\
\hline $2 \mathrm{I}$ & $\begin{array}{l}\text { Medium-term Development Plan of Inland } \\
\text { Waterways and Ports of the Republic of } \\
\text { Croatia, 2009-2016 }\end{array}$ & 2009.-20I6 & $\begin{array}{l}\text { Ministry of Sea, } \\
\text { Transport and } \\
\text { Infrastructure }\end{array}$ & Completed \\
\hline 22 & $\begin{array}{l}\text { Strategy for Broadband Development in the } \\
\text { Republic of Croatia, 2012-2015 }\end{array}$ & 2OI2-2OI5 & $\begin{array}{l}\text { Ministry of Sea, } \\
\text { Transport and } \\
\text { Infrastructure }\end{array}$ & Completed \\
\hline 23 & Water Management Strategy & $2008-2038$ & $\begin{array}{l}\text { Croatian Waters, } \\
\text { Public Enterprise }\end{array}$ & Completed \\
\hline 24 & $\begin{array}{l}\text { Waste Management Strategy of the Republic } \\
\text { of Croatia }\end{array}$ & $2005-2025$ & $\begin{array}{l}\text { Ministry of } \\
\text { Environment and } \\
\text { Nature Protection }\end{array}$ & Completed \\
\hline
\end{tabular}


Action Plan for Organic Agriculture

Development in the Republic of Croatia, 2OII-20I6

National Health Care Strategy, 2012-2O2O

National Plan for the Development of Clinical Hospital Centres, Clinical Hospitals, Clinics and General Hospitals in the Republic of Croatia, 20I4-20I6

30

Social Welfare Development Strategy of the Republic of Croatia, 2OII-2OI6

Strategy for Fighting Poverty and Social

3I Exclusion in the Republic of Croatia, 2014-2020

Plan for Deinstitutionalisation and Transformation of Social Welfare Homes and Other Legal Entities Engaged in Social Welfare in the RC, 2OII-2OI6 (2OI8)

National Strategy for the Rights of the Child in the Republic of Croatia, 2014-202O

National Strategy for the Creation of an

Enabling Environment for the Development

34 of Civil Society in the Republic of Croatia, $2 \mathrm{OI} 2$-2OI6

National Policy for Gender Equality in the Republic of Croatia, 2OII-2OI5

National Strategy for Roma Integration in the Republic of Croatia, 20I3-202O

National Programme for the Protection and Promotion of Human Rights in the Republic of Croatia, 2013-2016

Strategy For Conservation, Protection and

38 Sustainable Economic Use of Cultural

Heritage of the Republic of Croatia, 2OII-20I5

39 Anti-corruption Strategy

$40 \quad$ Judiciary Development Strategy
$2015-2050$

2OI4-2O2O

2OII-2OI6

2OI2-2O2O

20I4-20I6

2OII-2OI6

2014-2O2O

(1)

2OII-2OI8

2014-2020

2OI2-2OI6

2OII-2OI5

2OI3-2O2O

2OII-2OI5

2008

and beyond

2013-20I8
Ministry of

Environment and

Nature Protection

Ministry of Agriculture

Ministry of Agriculture

Ministry of Health

Completed

Under

preparation

Ministry of Social

Welfare Policy and

Youth

Ministry of Social

Welfare Policy and

Youth

Completed

Completed

Ministry of Social Welfare Policy and Youth

Ministry of Social

Welfare Policy and

Youth

Office for Cooperation

with NGOs of the

Government of the RC

Gender Equality Office of the Government of the RC

Under

preparation

Under

preparation

Completed

Office for Human

Rights and Minority

Rights of the

Government of the RC

Office for Human

Rights and Minority

Rights of the

Completed

Government of the RC

Under

preparation

Completed

Completed

Completed

Ministry of Culture

Completed

Ministry of Justice

Completed

Ministry of Justice

Completed 